\title{
RUANG PASCAKOLONIAL DALAM THE GOD OF SMALL THINGS KARYA ARUNDHATI ROY
}

\author{
Endang Suciati \\ Fakultas Bahasa dan Sastra, Unipdu Jombang \\ Email: endangsuciati24@gmail.com
}

\begin{abstract}
Abstrak
Makalah ini membahas tentang konstruksi ruang dalam novel The God of Small Things karya Arundhati Roy dengan pijakan teori ruang pascakolonial oleh Sara Upstone yang bertujuan untuk mengetahui representasi Barat dan Timur dalam struktur ruang pascakolonial India, baik di dalam maupun di luar ruang domestik, beserta strategi spasial pascakolonial yang digunakan. Hal ini dikarenakan novel The God of Small Things tampak membicarakan kondisi masyarakat pascakolonial India yang dualistik, sedangkan India sendiri termasuk salah satu masyarakat pascakolonial yang dualistik, yakni masih menjalankan tradisi India sekaligus menjalankan budaya peninggalan kolonial. Kedua konsep tersebut sama-sama memiliki aturan yang mengontrol kehidupan masyarakat dengan batas-batasnya yang justru bersifat menekan. Hasil analisis menunjukkan bahwa dalam konteks ruang domestik dan sekitarnya, novel The God of Small Things menunjukkan representasi Barat dan Timur yang akhirnya memunculkan transgresi dan chaos. Kekacauan tersebut memicu adanya post-space yang terjadi di luar rumah. Suatu ketika, post-space juga bisa dilakukan di dalam rumah. Dengan demikian, novel ini selalu berupaya membongkar konstruksi yang dibangun, termasuk konstruksi pascakolonial sendiri, karena permasalahan berangkat dari kondisi pascakolonial dalam masyarakat India yang dualistik.
\end{abstract}

Kata Kunci: kolonial, pascakolonial, chaos, post-space.

This paper discussed about the construction of space in The God of Small Things novel by Arundhati Roy using post-colonial space theory by Sara Upstone to find out the representation of the West and the East inside and and outside the domestic space including the post-colonial strategy used. It was because The God of Small Things seemed to talk about the condition of the dualistic post-colonial Indian society. Then, India itself is one of the dualistic postcolonial societies which means that it still holds its own traditions and runs the culture left by the colonial. Both colonial and Indian culture had their own rules with their borders that controlled people's life but they were repressive to the society. The result of this analysis proved that in the context of domestic space and its surroundings, The God of Small Things showed the representation of the West and the East that caused transgression and chaos. The chaos led to post-space outside the home. Once, the novel showed that the post-space could also be done inside the home. Thus, the novel was deconstructing the construction, including the construction of post-colonial itself. It happened since the problem began in dualistic conditions of post-colonial Indian.

Keywords: colonial, post-colonial, chaos, post-space.

\section{Pendahuluan}

India merupakan masyarakat

pascakolonial, hal ini ditandai dengan pengalaman kolonial India misalnya dari serangkaian peristiwa penjajahan oleh bangsa Eropa dari abad ke-18 sampai India memperoleh kemerdekaannya. Menurut Gopal (2009), penjajahan di India mulai pada tahun 1757 dengan Pertempuran Plassey yang memberi kemenangan pada British East India Company. Kemudian pada tahun 1857, terjadi perang kemerdekaan pertama yang dikenal oleh Inggris sebagai Sepoy Mutiny. Sederetan peristiwa besar yang berkaitan dengan pendudukan penjajah terjadi di India hingga pada tahun 1945, dan pada tahun 1947 India memperoleh kemerdekaannya. Serangkaian peristiwa ini menunjukkan bahwa India memiliki pengalaman kolonial: India pernah dijajah dan dikuasai oleh pihak kolonial.

Peninggalan kolonial, Inggris, sangat terlihat jelas dalam masyarakat pascakolonial India. Menurut Kulper (2011: 16), salah satunya adalah aturan Inggris untuk menggunakan bahasa Inggris di lingkungan formal. Hal ini 
menjadikan India sebagai salah satu negara terbesar yang menggunakan bahasa Inggris. Dalam hal pendidikan, misalnya dalam penerapan kurikulum, seperti dinyatakan oleh Stein (2010: 233), perkembangannya mengacu ke arah "kebarat-baratan", yang berarti bahwa pengajaran berdasarkan kurikulum sekolah yang lebih tinggi, misalnya sekolah profesi hukum yang ada di Inggris yang menggunakan bahasa Inggris sebagai pengantarnya.

Meskipun India merupakan masyarakat dan kebudayaan bekas jajahan Eropa, masyarakat India tidaklah pasif. Masyarakat pascakolonial India tetap melestarikan budaya nenek moyang, di samping menjalankan budaya peninggalan penjajah. Menurut Sigh (2005: 132), di akhir kolonialisme, India bisa memodernisasi dirinya sendiri dengan budaya yang dimiliki meskipun India tetap mengambil sisi intelektual kolonial. Dalam bidang sastra, seperti ditulis dalam bukunya, Upamayu Pablo Mukerjee (2010: 3) menyatakan bahwa masyarakat pascakolonial India menulis karya sastra dalam bahasa Inggris, sehingga muncul Indian English Novel. Tulisan kontemporer dalam bahasa Inggris tersebut selain berisi kondisi masyarakat pascakolonial, juga mengandung kritikan terhadap rezim kolonial yang pernah berkuasa. Pernyataanpernyataan di atas menunjukkan bahwa sebagai masyarakat bekas jajahan, India tetap aktif, tidak diam menerima peninggalan penjajah. Aktivitas ini terwujud melalui kritikan terhadap rezim kolonial yang menunjukkan bahwa masyarakat merasa tertekan dengan rezim tersebut. Respon aktif yang ditunjukkan masyarakat India tersebut menjadikan India sebagai masyarakat yang berlapis atau dualistik, dalam arti mereka menjalankan tradisi India sendiri sekaligus konsep peninggalan kolonial. Sementara itu, tradisi maupun peninggalan kolonial memiliki aturan masing-masing, yang suatu ketika aturan tersebut cenderung menjadi tekanan bagi masyarakat India sendiri.

Salah satu Indian English Novel yang tampaknyaberisinilai-nilaikehidupan masyarakat pascakolonial India yang dualistik ini adalah The God of Small Things karya Arundhati Roy. Seting novel ini berada pada masa pascakolonial India, seperti pernyataan Tickell (2007: 3) bahwa seting yang diambil adalah Kerala (India) pada akhir tahun 1960an sampai awal tahun 1990an. Kondisi dualistik tersebut banyak terjadi dalam lingkungan domestik dan sekitarnya.

Dengan melihat fenomena bahwa masyarakat India adalah masyarakat yang dualistik dalam struktur ruang pascakolonial, di mana aturan ganda, Barat dan Timur, yang dimiliki menyebabkan masyarakat India cenderung tertekan, maka muncul permasalahan tentang bagaimana masyarakat India bisa keluar dari atau bertahan dalam aturan tersebut. Untuk mengetahui adanya upaya yang dilakukan oleh masyarakat pascakolonial India, maka novel The God of SmallThingsiniditeliti degan menggunakan teori ruang oleh Sara Upstone dalam dengan rincian masalah pertama: bagaimana Barat dan Timur direpresentasikan dalam struktur ruang di dalam dan di luar rumah dan kedua: bagaimana strategi spasial pascakolonial dalam menyiasati munculnya dampak yang ditimbulkan oleh representasi tersebut.

Teori yang akan digunakan dalam penelitian ini berkaitan dengan pascakolonialisme, khususnya rumah pascakolonial. Teori ini diuraikan pertama kali oleh Sara Upstone (2009) dalam bukunya Spatial Politics in the Postcolonial Novels. Di sini, akan diuraikan beberapa pengertian tentang kolonialisme, pascakolonialisme, dan selanjutnya konsep ruang, termasuk chaos dan post-space, menurut Upstone, serta rumah sebagai salah satu level ruang.

\section{Kolonialisme dan Pascakolonialisme}

Terdapat banyak pendapat tentang kolonialisme. Pertama, secara umum kolonialisme didefinisikan sebagai penguasaan atas kontrol terhadap tanah dan barang milik pihak lain. Sedangkan, pada kolonialisme modern penguasaan tersebut tidak terbatas pada tindakan perampasan atas benda-benda dan kekayaan milik wilayah yang dikuasai, tetapi di dalamnya terdapat upaya penstrukturan kembali bangunan perekonomian bangsa yang dikuasai, 
yang mengakibatkan adanya aliran sumber daya manusia dan alam di antara penguasa dan wilayah yang dikuasai (Lombaa, 2005: 8-9). Berkaitan dengan kontrol atas teritori tersebut, pendapat kedua dinyatakan oleh Upstone (2009: 4) bahwa kolonialisme sebagai klaim terhadap wilayah atas nama penyebaran agama, pengembangan perekonomian, dan pengembangan wilayah (labenstrum), melihat kecocokan wilayah jajahannya sebagai empire, dan empire sebagai tujuan klaim atas wilayah tersebut.

Kemudian berkaitan dengan pascakolonialisme, Lombaa (2005: 16) menyatakan bahwa pascakolonialisme merupakan kontestasi atas dominasi kolonial dan warisan-warisan kolonialisme. Dengan kata lain, dominasi kolonial dan warisan-warisan kolonialisme itu akan dibongkar oleh konsep pascakolonial. Akan ditunjukkan bahwa kolonial yang mewariskan keteraturan sebenarnya tidak benar-benar bisa mewujudkan keteraturan yang diidamkan, dan masih ada jejak masa lalu yang dimiliki bangsa terjajah. Hal ini menyebabkan terjadinya kontestasi atau pertentanganpertentangan yang pada akhirnya memunculkan keberagaman.

Pendekatan pascakolonial yang akan digunakan di sini adalah pendekatan pascakolonial tentang ruang oleh Sara Upstone dalam bukunya Spatial Politics in the Postcolonial Novel. Pendekatan pascakolonial menurut Upstone menekankan pada politik ruang, dalam arti pascakolonial yang telah dipahami sebagai masa dimana suatu wilayah pernah ditempati dan dikontrol oleh kolonial, dan kolonial telah meninggalkan wilayah tersebut, oleh Upstone dianggap masih mempunyai ruang-ruang kolonial yang ditinggalkan pada wilayah jajahan meskipun secara fisik kolonial sudah tidak berada lagi pada ruang terjajah. Ruang-ruang tersebut oleh Upstone dikelompokkan menjadi beberapa level mulai dari bangsa, perjalanan, kota, rumah dan tubuh, dimana pada setiap ruang tersebut terdapat unsur politik yang ingin diungkap.

\section{Ruang dalam Pandangan Pascakolonialisme}

Dalam bukunya, Upstone menjelaskan strategi kontrol dengan konsep batas. Dijelaskan pula bahwa koloni bukan hanya mencakup sebuah komunitas masyarakat tertentu, namun juga wilayah dari komunitas tersebut (Upstone, 2009: 4). Konsep ruang berbatas ini ditanamkan pada masyarakat sebagai sesuatu yang tetap, terkontrol, absolut, dan natural. Konsep tentang batas yang ditanamkan pada masyarakat dan memiliki tujuan untuk melakukan kontrol, mempertahankan stabilitas, serta menghindarkan berbagai resistensi, terjaga dengan adanya penerimaan dan persetujuan masyarakat bahwa batas bersifat alamiah. Dengan demikian, seolah masyarakat tidak menyadari adanya konstruksi kolonial tentang batas tersebut. Kondisi inilah yang akan menjadikan masyarakat homogen, sehingga mudah dikontrol.

Dalam pandangan pascakolonial, ruang lebih bersifat cair, berbeda dengan harmonisasi dan idealisasi ala kolonial (Upstone, 2009: 11). Sara Upstone menawarkan gagasan bahwa penulis-penulis pascakolonial menciptakan ruang sebagai tempat berbagai kemungkinan dan resistensi, dengan merebut kembali kecairan ruang yang telah ditolak oleh konsep kolonial dalam gagasan ruang berbatasnya dan dengan memberikan lokasi-lokasi fungsi-fungsi politis (Upstone, 2009: 11). Ini berarti bahwa penulis pascakolonial ingin mengungkapkan chaos yang ada, dan membuka peluang untuk suatu perlawanan atau resistensi terhadap konstruksi kolonial.

Berbeda dengan pandangan kolonial, pandangan pascakolonial melihat ruangan berisi suara-suara heterogen, yang memiliki berbagai pengalaman, yang memberi penekanan pada perbedaan dan subjektivitas (Upsotone, 2009: 13). Suara-suara heterogen dan pengalaman inilah yang memunculkan chaos. Penyingkapan chaos tersebut tidak untuk menghilangkan semua stabilitas yang ada, melainkan lebih pada upaya pemanfaatannya dalam membongkar pandangan yang dianggap tetap dan menanamkan pola-pola pemahaman dan pengalaman-pengalaman yang baru sehingga dibutuhkan fluiditas ruang yang 
tidak bisa didapatkan dalam konsep kolonial maupun tradisi, atau pula dari konsep Barat dan Timur yang sudah dibatas-batasi tersebut; ini, pada akhirnya, memunculkan post-space. Menurut Upstone (2009: 15), post-space merupakan konsep yang berada di luar batas-batas kolonial maupun bata-batas tradisi, bahkan melampaui atau berada sebelum batas-batas tersebut muncul; ia juga bisa dikatakan suatu ruang yang hibrid, cair dan bergerak, sehingga tidak memiliki batasbatas lagi.

\section{Rumah dalam Pandangan Pascakolonial- isme}

Dalam lingkup yang lebih kecil, rumah (bagi kepentingan kolonial) merupakan salah satu konstruksi yang berperan untuk menjalankan fungsi politis dalam menegakkan nilai-nilai kolonial, dan peran ini ditampilkan pada rumah secara paradoks dalam idealisasi dan apolitisasi (Upstone, 2009: 115). Kolonial menggunakan rumahuntukmempropagandakanwacananegara kolonial dengan berbagai startegi. Strategi yang digunakan untuk menanamkan wacana tersebut dalam pemikiran masyarakat koloninya adalah dengan menjadikan rumah sebagai lokasi yang tetap, berakar, stabil, antitesis dari perjalanan. Kecairan dari rumah dikaburkan. Sedangkan, harmoni yang ideal tentang rumah dimunculkan dengan mempropagandakan pandangan bahwa rumah adalah lokasi penanaman nilai-nilai dan tingkah laku yang dianggap krusial untuk membentuk dan mempertahankan identitas nasional, serta merupakan perlindungan yang diperlukan dari perubahan sosial dan kondisi ekonomi yang tak terduga (Upstone, 2009: 117).

Di sisi lain, kritik pascakolonial mengaitkan rumah dengan pertarungan politis, sebagai ruang domestik lokasi terjadinya upaya resistensi dengan dimensi politis yang radikal (Upstone, 2009: 16). Bila representasi kolonial atas rumah mengaburkan ketidakteraturan dan memisahkan rumah dari politik di ruang publik, maka representasi pascakolonial justru menampilkan ketidakteraturan dan status politis dari rumah. Dapat dikatakan bahwa pascakolonial ini benar-benar ingin mengungkapkan bahwa rumah (sebagai ruang domestik) menolak isolasi rumah dari lingkungan yang lebih besar, misalnya nation, karena pascakolonial menganggap bahwa pertarungan politis tersebut ada.

Berkaitan dengan hirarki dan divisidivisi yang diterapkan oleh kekuasaan kolonial dalam rumah, tampak bahwa rumah memiliki sekat-sekat, batas-batas yang sudah tetap. Dengan ini, maka rumah pascakolonial akan mengungkap bahwa dalam hirarki serta batas rumah kolonial terdapat ketidakteraturan dan chaos (Upstone, 2009: 124). Dapat dikatakan pula bahwa pascakolonial juga ingin mengungkapkan chaos dalam rumah terjadi karena 'tidak semua penghuni rumah mendukung ideal kolonial' (Upstone, 2009:128). Ketegangan yang tejadi dalam rumah hendak diungkap, dan kecairan pun akan dimunculkan. Dengan demikian, jelas bahwa rumah pascakolonial tidak lagi untuk melayani kepentingan kolonial, tetapi untuk melayani tujuan-tujuan lain yang akhirnya merusak relasi kekuasaan yang telah dibangun oleh konsep kolonial (Upstone, 2009: 131).

Dalam pembahasan ini dijelaskan konstruksi ruang, baik yang ada di dalam maupun di luar rumah Ayemenem, yang mengarah pada konstruksi ruang kolonial maupun tradisi India. Selain itu, dibahas pula bagaimana masyarakat merasa tertekan dengan konstruksi yang ada beserta strategi spasial yang ada dalam menyiasati adanya representasi ruang Barat maupun Timur tersebut.

\section{Struktur Ruang di dalam Rumah Ayemen- em}

Rumah Ayemenem adalah rumah tua peninggalan dari orang tua Reverend John Ipe (Pendeta Kristen Syria yang terberkati) yang kemudian dihuni oleh anaknya, Pappachi, beserta menantunya, Mammachi, dua anak mereka (Chacko dan Ammu) serta adik perempuan Pappachi yang bernama Baby Kochamma. Terdapat pula anak kembar Ammu yang bernama Rahel dan Estha. Keluarga penganut agama Kristen Syria ini kedudukannya setara dengan kasta Brahmana. Ini dijelaskan 
melalui kutipan berikut: "Twenty percent of Kerala's population were Syrian Christians, who believed that they were descendants of the one bundred Brabmins whom St. Thomas the Apostle converted to Christianity when he traveled East after the Resurrection" (Roy, 2008: 65). Dalam rumah itu juga ada pembantu yang bernama Kochu Maria yang berasal dari kaum paravan atau kaum untouchable yang menduduki kasta paling rendah bahkan tidak berkasta di lingkungan Kerala India.

Pada saat Pappachi masih hidup, Rumah Ayemenem digambarkan sebagai rumah tua yang megah. Namun, rumah ini juga menunjukkan keterasingannya, seolah-olah tidak peduli terhadap penghuni yang ada di dalamnya.

"It was a grand old house, the Ayemenem House, but aloof-looking. As though it had little to do with the people who lived in it. Like an old man with rheumy eyes watching children play, seeing only transience in their shrill elation and their wholehearted commitment to life" (Roy, 2008: 157).

Rumah Ayemenem yang tua, yang berada di daerah Kerala India, menunjukkan bahwa rumah ini adalah rumah India. Kata "tua" yang terlekat pada pengertian rumah ini mengindikasikan bahwa rumah tersebut familiar dengan apa yang dimilikinya. Namun, kata "tua" ini justru disandingkan dengan keterasingan, sifat menjauh, yaitu kata aloof-looking. Hal ini didukung dengan pengibaratan seorang lelaki tua yang bersifat tak acuh. Menjauh dan menyendiri adalah konsep kolonial, sehingga dapat dikatakan bahwa rumah ini memiliki konstruksi yang campuran atau dualistik di mana usianya yang tua (yang dianggap sebagai rumah India) tidak menjadikan ia akrab dengan yang dimiliki; ia justru menjadi asing, seperti layaknya kolonial. Dari sini, terlihat ada border atau batas, yaitu rumah tua yang semestinya dekat menampakkan diri sebagai sesuatu yang jauh atau aloof-looking dan, pada akhirnya, batas ini mengarah pada sesuatu yang dianggap Barat atau kolonial dengan sesuatu yang dianggap Timur.

Sementara itu, lantai telah terbuat dari semen merah yang dicampur dengan hampir sembilan ratus putih telur yang menjadikannya mengkilap. Penggunaan semen sebagai lantai menjadi batas sesuatu yang rigid atau kolonial dan berkaitan dengan kasta. Artinya, tidak semua orang boleh masuk dan menginjak lantai ini.

"Pappachi would not allow Paravans into the bouse. Nobody would. They were not allowed to touch anything that Touchables touched. Caste Hindus and Caste Christians. Mammachi told Estha and Rahel that she could remember a time, in her girlhood, when Paravans were expected to crawl backwards with a broom, sweeping away their footprints so that Brabmins or Syrian Christians would not defile themselves by accidentally stepping into a Paravan's footprint" (Roy, 2008: 70).

Kasta rendah tidak boleh masuk rumah melewati lantainya yang indah mengkilap karena dianggap akan mengotorinya. Batas ini merupakan gabungan antara konsep tradisi dan kolonial; tradisi karena sistem kasta masih kuat dipegang pada masa kakeknya tersebut, dan kolonial karena bentuk lantainya yang rigid. Konsep kolonial berhubungan erat dengan sesuatu yang tetap, sesuatu yang bersih, seperti lantai yang dimiliki, sesuatu yang tidak mudah berubah.

Konstruksi ruang yang ada pada Rumah Ayemenem tersebut menunjukkan adanya campuran. Hal ini berkaitan erat dengan leluhur pemilik rumah yang sudah mengalami percampuran antara tradisi India dan peninggalan kolonial. Konstruksi tersebut juga bisa dilihat dari nilai-nilai yang diyakini oleh penghuni rumah, yang mengarah pada konsepkonsep Barat dan Timur, dan order serta border yang dimiliki dalam rumah ini. Hal ini bisa dilihat pula beberapa tahun kemudian ketika ayah Baby Kochamma sudah meninggal dan rumah dikuasai oleh saudara laki-laki Baby Kochamma, Pappachi, yang tinggal di sana bersama istrinya, anaknya, serta cucu-cucunya.

Anak kembar perempuan dan laki-laki, Rahel dan Estha, juga dibatasi oleh aturanaturan yang ada di rumah. Batas dan rule yang ada dalam Rumah Ayemenem bertujuan untuk 
menciptakan suatu keteraturan, namun pada kenyataannya order itu sulit diterapkan.

Baby Kochamma merupakan wanita tertua-selain Mammachi-di rumahnya. Di masa mudanya ia mendapatkan pendidikan agama Kristen dan Katolik dan kesempatan sekolah di Amerika. Ia berupaya mendidik anak-anak Ammu dengan aturannya yang tegas dan kaku. Anak-anak mendapatkan pelajaran bahasa Inggris yang ketat di dalam rumah, terlebih satu minggu sebelum penyambutan sepupu yang datang dari Inggris, Sophie Mol. Mereka dilarang berbicara dalam bahasa Malayalam-bahasa asli Kerala India-tetapi diwajibkan melafalkan berbagai ucapan dalam bahasa Inggris dengan tepat.

"That whole week Baby Kochamma eavesdropped relentlessly on the twins' private conversations, and whenever she caught them speaking in Malayalam, she levied a small fine which was deducted at source. From their pocket money. She made them write lines"impositions" she called them-I will always speak in English, I will always speak in English. A bundred times each" (Roy, 2008: 36).

Dari kutipan tersebut, tampak bahwa Baby Kochamma akan menghukum anakanak jika tertangkap menggunakan bahasa Malayalam. Mereka harus mengucapkan dalam kaidah bahasa Inggris yang tepat. Hal ini menandakan bahwa pihak penguasa di Rumah Ayemenem sangat ketat dalam menjaga kontrol atas bahasa Inggris.

Demikian pula dalam memilih teman, rumah sangat membatasi teman berdasarkan kasta.

"And please stop being so over-familiar with that man!" Baby Kochamma said to Rahel. "Over-familiar?" Mammachi said. "Who is it, Chacko? Who's being over-familiar?" "Rahel," Baby Kochamma said. "Overfamiliar with who?" "With whom," Chacko corrected his mother. "All right, with whom is she being over-familiar?" Mammachi asked. "Your Beloved Velutha-whom else?" Baby Kochamma said, and to Chacko, "Ask him where he was yesterday. Let's bell the cat once and for all” (Roy, 2008: 175).

Penguasa rumah tidak menghendaki anak-anak berteman dengan Velutha secara overfamiliar atau terlalu akrab. Hal ini dikarenakan Velutha berasal dari kasta terendah di daerah mereka, sementara keluarga Ayemenem termasuk dalam kasta tertinggi-setara Brahmana. Baby Kochamma ingin mempertahankan kontrol atas aturan yang ada pada Ayemenem, yaitu tradisi yang mengharuskan mereka tidak berteman akrab dengan kaum paravan. Hal ini menandakan bahwa sistem tradisi India yang berupa kasta masih dipegang kuat.

Ayemenem perlahan ditinggalkan oleh pemegang kontrol aturannya, Pappachi telah meninggal, namun jejak-jejak order tidak begitu saja hilang dan perlahan chaos mulai muncul. Ketika kembar ini telah dipisah, dan Rahel menginjak dewasa dan tinggal bersama nenek dan pamannya di Ayemenem karena ibunya telah meninggal, maka kekacauan perlahan muncul.

"After Ammu died (after the last time she came back to Ayemenem, swollen with cortisone and a rattle in her chest that sounded like a faraway man shouting), Rahel drifted. From school to school. She spent her holidays in Ayemenem, largely ignored by Chacko and Mammachi (grown soft with sorrow, slumped in their bereavement like a pair of drunks in a toddy bar) and largely ignoring Baby Kochamma. In matters related to the raising of Rahel, Chacko and Mammachi tried, but couldn't. They provided the care (food, clothes, fees), but withdrew the concern" (Roy, 2008: 16).

Setelah kematian Ammu, kehidupan Rahel semakin tak terurus dari sisi kasih sayang. Ia berpisah dengan ibunya dan berada dalam pengasuhan nenek serta pamannya yang hanya memberikan kebutuhan fisik saja. Ia berpindahpindah sekolah. Hal ini menunjukkan bahwa, ketika ibunya meninggal dan sebelum itu penegak peraturan yang lain juga telah meninggal (Pendeta Ipe dan Pappachi), aturan dalam Ayemenem semakin diabaikan. Rumah menjadi ruang yang semakin chaotic, di mana hubungan 
keluarga semakin renggang meski berada dalam satu atap, Rumah Ayemenem.

Sementara itu, kondisi fisik bagian dalam rumah juga menunjukkan kondisi Ayemenem ketika kontrol semakin memudar, seperti dalam kutipan berikut.

"Filth had laid siege to the Ayemenem House like a medieval army advancing on an enemy castle. It clotted every crevice and clung to the windowpanes. Midges whizzed in teapots. Dead insects lay in empty vases. The floor was stick.y. White walls had turned an uneven gray. Brass hinges and door handles were dull and greasy to the touch. Infrequently used plug points were clogged with grime. Lightbulbs had a film of oil on them. The only things that shone were the giant cockeroaches that scurried around like varnished gofers on a film set. Baby Kochamma had stopped noticing these things long ago. Kochu Maria, who noticed everything, had stopped caring” (Roy, 2008: 84).

Digambarkan bahwa kebusukan menyerang Ayemenem. Kebusukan itu menempel di setiap celah dan bergantung pada kaca jendela. Serangga yang dulu menjadi bahan penelitian Pappachi sebagai ahli serangga, kini mati pada vas kosong. Lantai yang dulu bersih, kini semakin lengket. Temboknnya yang putih sekarang menjadi abu-abu. Gagang pintu menjadi rapuh, yang memungkinkan pintu tidak lagi bisa tertutup dengan rapat. Hanya kecoa raksasa saja yang berkilau, berjalan terburu-buru dalam rumah, karena kecoa biasanya berada pada tempat yang kotor. Ini membuktikan bahwa Baby Kochamma, satu-satunya orang yang masih tinggal di sana bersama pembantunya, tidak lagi memperdulikan kontrol rumah serta kebersihannya. Aturan telah diabaikan, termasuk oleh Kochu Maria yang ikut berhenti menjalankan apa yang dahulu bisa menjaga dan menegakkan aturan di rumah.

Berbagai kondisi ini disebabkan semakin terbukanya rumah terhadap dunia luar. Batas rumah semakin longgar, bahkan orang yang masih tersisa yang dulunya selalu menegakkan aturan-Baby Kochamma dan Kochu Mariasemakin membuka diri untuk hal lain yang menyusup ke rumah. Hal ini yang mengalihkan perhatian mereka terhadap kontrol rumah berkaitan dengan keteraturan taman, kamar, dan ruang-ruang lain, sebagaimana dilihat pada kutipan The reason for this sudden, unceremonious dumping was a new love. Baby Kochamma had installed a dish antenna on the roof of the Ayemenem house. She presided over the world in her drawing room on satellite TV. (Roy: 27). Kecintaan Baby Kochamma dalam merawat kebun telah hilang, dan beralih ke TV satelit dengan antena yang dipasang pada atap Rumah Ayemenem. Dia memanfaatkan ruang kerja untuk menonton TV dan menguasai dunia-melihat segala yang ada di luar rumahmelalui TV. Dalam hal ini, rumah juga telah memberikan toleransi atas aturan yang dibuatnya. Ia membiarkan peluang yang ada di luar rumah masuk melalui TV satelit.

Beberapa kutipan di atas menunjukkan bahwa konstruksi ruang Rumah Ayemenem menunjukkan adanya campuran antara konsep Barat dan Timur yang dapat dilihat dari konstruksi fisik ruangnya maupun aturan yang berlaku. Aturan-aturan tersebut mengontrol kehidupan manusia yang tinggal di dalam rumah. Namun demikian, semakin lama konsep Barat maupun Timur tersebut semakin luntur; pembatasan yang mengarah pada konsep Barat dan Timur pada rumah mengarah pada munculnya chaos.

\section{Struktur Ruang di Luar Rumah Ayemenem}

Pada level sosial, yaitu dalam kampung daerah Ayemenem, masyarakat menunjukkan keberagamannya yang pada akhirnya menciptakan batas-batas. Kutipan berikut mengisahkan kondisi Ammu saat radio transistor memutarkan lagu kesayangannya, dapat dilihat respon yang ditunjukkan masyarakat terhadapnya.

"On the days that the radio played Ammu's songs, everyone was a little wary of her. They ensed somehow that she lived in the penumbral shadows between two worlds, just beyond the grasp of their power. That a woman that they had already damned, now had little left to lose, and could therefore be dangerous. So on the days that the radio played Ammu's songs, 
people avoided her, made little loops around her, because everybody agreed that it was best to just Let Her Be" (Roy, 2008: 43).

Ketika mendengarkan lagu kesayangannya, sifat Ammu akan langsung berubah, dan orang-orang yang melihatnya selalu waspada. Masyarakat telah mengutuknya karena Ammu adalah janda dari lelaki Hindu yang kembali ke rumah orangtuanya dan diketahui berselingkuh dengan melakukan hubungan seksual bersama Velutha di sungai. Dalam kondisi ini, masyarakat menganggap ia gila dan berbahaya. Mereka menghindarinya dan bersepakat membiarkan Ammu dalam kondisi tersebut. Dengan demikian, dapat dikatakan bahwa tetangga Ayemenem sepakat bahwa perselingkuhan Ammu dan Velutha yang berbeda kasta adalah sebuah tindakan di luar batas yang disepakati oleh masyarakat. Dengan demikian, masyarakat masih menjaga kontrol atas keteraturan terhadap batas antara kasta tinggi dan kasta rendah, serta interaksi yang mereka lakukan. Dalam kondisi seperti ini, rumah Ayemenem-yang diwakili oleh Ammumelawan aturan Timur atau tradisi India tentang kasta. Oleh karena ia tidak memperhatikan aturan tradisi dalam pergaulan antarkasta, sementara masyarakat masih memegang aturan tersebut, tentunya ini menjadi tekanan bagi Ammu.

Selain itu, terdapat pula tetangga Ayemenem, comrade K.N.P. Pillai, yang membanggakan sifat keinggrisan dalam keluarganya. Ketika Chacko bertamu ke rumahnya, ia meminta anaknya untuk menunjukkan kemampuan dalam membaca puisi Inggris atau berpidato dalam bahasa Inggris, seperti dalam kutipan:

"Lenin Mon, tell Comrade Uncle the one Pappa taught you. Friends Romans countrymen ..." Lenin continued his nasal treasure bunt. "Come on, Mon, it's only our Comrade Uncle-" Comrade Pillai "Friends Roman: countrymen lend me your-?" Lenin's unblinking gaze remained on Chacko. Comrade Pillai tried again. "Lend me your-?" Lenin shouted from the yard, over the sound of a passing bus. "I cometobery Caesar, not to praise bim. Thee-vu that mendoo lives after them, The goodisoft interred with their bones..." He shouted it fluently, without faltering once. Remarkable, considering he was only six and didn't understand a word of what he was saying. Sitting inside, looking out at the little dust devil whirling in his yard (future service contractor with a baby and Bajaj scooter), Comrade Pillai smiled proudly" (Roy, 2008: 125).

Berdasarkan kutipan di atas, dapat dikatakan bahwa kebanggaan Comrade terhadap anak kecilnya untuk membaca puisi berbahasa Inggris yang telah dia ajarkan menunjukkan pula bahwa Comrade membanggakan keinggrisannya. Meskipun anaknya tidak mengerti bahasa tersebut, tetapi Lenin, anak Comrade, tetap mempraktikkannya sehingga mampu berbahasa Inggris seolah menjadi rule bagi anak di rumah Comrade meskipun rule tersebut tidak sekaku yang ada dalam rumah Ayemenem karena tidak ada hukuman jika ucapan tidak tepat.

Selain ruang yang berada jauh dari luar rumah Ayemenem, seperti telah disinggung di atas, terdapat pabrik yang berada dekat dengan Ayemenem. Di antara sungai, rumah, dan pabrik ini adalah milik keluarga Ayemenem. Pabrik tersebut bisa dilihat dari jendela di rumah Ayemenem.

"From the dining-room window where she stood, with the wind in her hair, Rabel could see the rain drum down on the rusted tin roof of what used to be their grandmother's pickle factory Paradise Pickles \& Preserves. It lay between the house and the river. They used to make pickles, squashes, jams, curry powders and canned pineapples. And banana jam (illegally) after the FPO (Food Products Organization) banned it because according to their specifications it was neither jam nor jelly. Too thin for jelly and too thick for jam. An ambiguous, unclassifiable consistency, they said" (Roy, 2008: 15).

Pabrik selai dan acar tersebut dulunya memproduksi acar, selai, bubuk bumbu kari, dan nanas kalengan. Sebelum dilarang oleh FDO, pabrik ini juga memproduksi selai pisang secara ilegal karena dianggap selai pisang yang 
diproduksi terlalu encer untuk ukuran jeli dan terlalu kental untuk ukuran selai; klasifikasinya ambigu karena tidak konsisten menurut FDO. Hal ini juga nantinya tercermin dari orang-orang yang berkecimpung dalam pabrik tersebut, yakni bahwa mereka yang dari awal sudah campuran antara konsep kolonial-yang memiliki pabrikjuga masih memegang konsep tradisi India yang berupa kasta.

Jika pabrik dianggap sebagai space tersendiri, maka ia termasuk dalam space kolonial di mana pabrik merupakan simbol kapitalisme. Sementara itu, orang-orang yang bekerja di pabrik dibayar, baik atas dasar pekerjaaannya atau sesuai profesinya maupun keluar dari semua itu (misalnya pekerja pabrik dibayar karena mereka adalah wanita cantik yang mau masuk kamar pemilik pabrik untuk urusan yang lain). Chacko was a self-proclaimed Marxist. He would call pretty women who worked in the factory to his room, and on the pretext of lecturing them on labor rights and trade union law, flirt with them outrageously (Roy: 62). Kemudian dalam kutipan selanjutnya, Mammachi, ibu Chacko yang juga pemilik pabrik tersebut, menyelipkan uang kepada wanita-wanita pekerja pabrik yang masuk ke kamar Chacko sebagai upah di luar gaji kerja di pabrik. She secretly slipped them money to keep them happy. They took it because they needed it (Roy: 161). Dengan demikian, ada unsur personal dalam pemberian bayaran pada pekerja pabrik tersebut. Unsur profesional telah tercampur dengan kepentingan personal, sehingga pabrik tidak lagi ketat dalam mempertahankan batas yang berupa profesionalitas.

Sementara itu, dalam konteks lain, pabrik juga bisa menjadi ruangyang nyaman bagi kembar Rahel dan Estha untuk keluar dari rumah ketika mereka merasa tertekan dengan aturan yang ada di dalam rumah. Estha menyukai pabrik dalam kondisi pengap dan gelap dibandingkan dengan rumah megah Ayemenem. Hal ini menandakan bahwa pelanggaran tidak dapat dilakukan di dalam rumah tetapi di luar rumah.

"It was dark inside, lit only by the light that filtered through the clotted gavie doors, and a beam of dusty sunlight (that Ousa didn't use) from the skylight. The smell of vinegar and asafetida stung his nostrils, but Estha was used to it, loved it. The place that he found to Think in was between the wall and the black iron cauldron in which a batch of freshly boiled (illegal) banana jam was slowly cooling" (Roy, 2008: 90).

Meskipun tempat tersebut gelap dan penuh dengan bau cuka yang digunakan dalam proses pembuatan acar dan selai di pabrik, Estha sudah terbiasa dengan kondisi tersebut. Artinya, bagaimanapun keadaan pabrik, sekalipun menimbulkan bau, Estha telah terbiasa dengannya. Tempat yang dicari Estha untuk berpikir dan membuat rencana-rencana tersebut adalah pabrik acar dan selai. Tempat tersebut berada di antara tembok dan panci besi berwarna hitam.

Berdasarkan paparan di atas, dapat dikatakan bahwa kondisi di luar rumah Ayemenem juga memiliki batas, namun batas tersebut tidak sekaku yang ada di dalam rumah terlebih ketika pengontrol aturan rumah masih hidup. Namun demikian, batas di luar rumah lebih longgar daripada yang di dalam rumah. Hal ini dapat dilihat dari adanya potensi munculnya tindakan di luar batas oleh beberapa tokoh yang dilakukan di luar rumah.

\section{Strategi Spasial Pascakolonial di Dalam dan di Luar Rumah Ayemenem}

Pada paparan di atas, dikatakan bahwa kondisi di luar rumah Ayemenem dianggap lebih cair daripada kondisi di dalam rumah. Berbagai trasgresi yang muncul akibat pembatasan yang ada di dalam rumah kemudian mengarah pada ruang di luar rumah Ayemenem. Ruang di luar rumah yang sering muncul dalam novel ini adalah sungai. Sungai menjadi space tersendiri di mana batas, yang dianggap sebagai Barat maupun Timur, melebur.

Dalam kisah Ammu, ketika berada pada kondisi tertekan karena batas dan aturan tradisi yang mengikatnya, yang menjadikan ia kehilangan hak untuk menempati ruang di rumah Ayemenem, salah satu hal yang muncul 
dalam pikirannya adalah sungai.

"For herself-she knew that there would be no more chances. There was only Ayemenem now. A front verandah and a back verandah. A hot river and a pickle factory" (Roy: 42).

Setelah bercerai dengan suaminya yang beragama Hindu Bengali, tidak ada tempat kembali lagi bagi dia kecuali di rumah Ayemenem. Yang dibayangkan oleh Ammu hanyalah tempat tertentu yang ada di rumah Ayemenem, yaitu teras depan dan belakang serta di luar Ayemnem yaitu sungai dan pabrik. Teras depan dan belakang adalah bagian dari rumah yang tidak benar-benar berada di dalam maupun di luar, yang berarti bahwa teras menempel di rumah namun tidak berada di dalam, sehingga dimungkinkan bahwa teras ini bukan suatu ruang yang benar-benar tertutup maupun benarbenar terbuka.

Sungai menjadi tempat Velutha dan Ammu bertemu dan melakukan pelanggaran, yaitu perselingkuhan dengan melakukan hubungan seksual, sesuatu yang tidak sesuai dengan aturan rumah Ayemenem. Ammu dan Velutha, ketika sama-sama berada pada kondisi tertekan oleh aturan, memiliki pemikiran yang sama untuk menuju suatu tempat yang lebih bebas dari kontrol dibandingkan dengan rumah Ayemenem, yaitu Sungai Meenachal.

"He began to swim towards her. Quietly. Cutting through the water with no fuss. He had almost reached the bank when she looked up and saw him. His feet touched the muddy riverbed. As he rose from the dark river and walked up the stone steps, she saw that the world they stood in was his. That he belonged to it. That it belonged to him. The water. The mud. The trees. The fish. The stars. He moved so easily through it" (Roy, 2008: 315).

Velutha, yang malam itu juga berenang ke sungai, bergerak menepi ke arah Ammu dan Ammu melihat Velutha yang hampir mencapai tepian. Ammu merasa bahwa tanah yang mereka injak-sungai-adalah milik Velutha, dan sebaliknya Velutha juga milik sungai, airnya, lumpurnya, ikan-ikannya, pohon-pohon, dan bintang yang ada di atasnya. Inilah yang menjadikan Velutha bergerak dengan mudah di sungai dan berenang di arusnya. Sungai yang merupakan space yang cair, yang bergerak, bisa menerima kedatangan Ammu yang berasal dari keluarga Kristen Syria; sungai tidak menolaknya.

Pelanggaran serupa mereka lakukan di tempat yang sama, yaitu di Sungai Meenachal, sampai pada malam ketiga belas, sebelum semua tindakan mereka terungkap. Even later, on the thirteen nights that followed this one, instinctively they stuck to the Small Things. The Big Things ever lurked inside. They knew that there was nowhere for them to go. They had nothing. No future. So they stuck to the small things (Roy: 320). Mereka berdua memahami konsekuensi yang dilakukan, bahwa akan ada hal besar yang mereka hadapi. Mereka juga sadar bahwa tidak ada tempat lagi bagi mereka untuk dituju. Ammu dengan kondisinya yang tersisih di Ayemenem, dan Velutha sebagai tokoh dengan kasta terendah yang selalu disisihkan pula, terlebih ketika pelanggaran itu diketahui orang lain, merasa tidak akan memiliki masa depan lagi. Oleh karena itu, mereka menikmati hal-hal kecil bersama, sebagai orang yang dianggap kecil. Perbuatan ini hanya bisa ia lakukan di sungai karena Sungai Meenachal tidak menetapkan batas bagi siapapun yang masuk ke dalamnya, sekalipun dia adalah orang yang tersisih dan tidak memiliki tempat di masyarakat.

Bagi anak-anak, sungai juga menjadi space yang cair bagi kembar Rahel-Estha. Ketika mereka berada dalam kondisi sangat tidak nyaman, dengan aturan yang diharuskan oleh keluarganya untuk berperilaku seperti orang Inggris saat menyambut tamu Inggris, maka Rahel-Estha lebih memilih untuk bersembunyi dibalik kelambu kotor yang ada di bandara, sembari memikirkan tentang sungai. The dirty airport curtain was a great comfort and a darkness and a shield. (Roy: 140). Bagi Rahel, dalam kondisi seperti yang ia alami dalam penjemputan Sophie, di mana dia mendapat banyak ketidaknyamanan, maka kelambu kotor di bandara adalah tempat yang nyaman baginya. Di balik kelambu tersebut, Rahel memikirkan sungai, biarpun Ammu 
marah padanya atas sikap yang ditunjukkam oleh Rahel.

\begin{abstract}
"All right," Ammu said. "That's enough. Both of you. Come out of there, Rabel!" Inside the curtain, Rahel closed her eyes and thought of the green river, of the quiet deep-swimming fish, and the gossamer wings of the dragonflies (that could see bebind them) in the sun. She thought of her luckiest fishing rod that Velutha had made for her. Yellow bamboo with a float that dipped every time a foolish fish enquired. She thought of Velutha and wished she was with bim" (Roy, 2008: 141).
\end{abstract}

Dengan menutup matanya, Rahel memikirkan sungai yang hijau. Ia merasa sungai itu nyaman karena sungai itu tidak mengikat dia dengan aturan-aturan, baik yang menyerupai orang Inggris maupun yang melarang dia berteman dengan penduduk berkasta rendah. Justru teman berkasta rendahlah-Veluthayang dibayangkan Rahel, yang menikmati waktu bahagianya di sungai. Pikiran ini muncul pada saat batas-batas antara Barat dan Timur mengatur Rahel dalam bersikap. Maka di sinilah sungai berperan menjadi alternatif penulis, bahwa aturan yang dibawa oleh tradisi (misalnya dalam memilih teman atas dasar kasta) tidak dihiraukan ketika berada di sungai, tidak berlaku juga ketetapan yang diinginkan oleh konsep Barat tentang sikap yang meniru gaya orang Inggris. Ini semua tidak perlu dilakukan oleh anak-anak ketika mereka berada di sungai.

Berbagai peristiwa di atas terjadi ketika Rahel-Estha masih anak-anak, ketika ibu mereka masih tinggal di Ayemenem. Setelah itu, si kembar dipisah, dan ibu mereka harus pergi meninggalkan Ayemenem. Kondisi sungai dimunculkan kembali setelah dua puluh tiga tahun ditinggalkan Rahel-Estha. Velutha sudah meninggal, dan kondisi masyarakat Ayemenem juga telah berubah.

"Years later, when Rabel returned to the river, it greeted her with a ghastly skull's smile, with holes where teeth had been ... Downriver, a saltwater barrage had been built, in exchange for votes from the influential paddy-farmer lobby. The barrage regulated the inflow of salt water from the backwaters that opened into the Arabian Sea. So now they had two harvests a year instead of one. More rice-for the price of a river. Despite the fact that it was June, and raining, the river was no more than a swollen drain now. A thin ribbon of thick water that lapped wearily at the mud banks on either side, sequined with the occasional silver slant of a dead fish. It was choked with a succulent weed, whose furred brown roots waved like thin tentacles underwater. Bronze-winged lily-trotters walked across it. Splay-footed, cautious" (Roy, 2008: 118).

Ketika kondisi rumah semakin chaotic setelah sekian lama ditinggalkan oleh pemegang kuasa atas kontrolnya, dan kontrol semakin longgar, maka penghuni rumah tidak perlu lagi menuju sungai untuk menghindari kekakuan aturannya. Pelanggaran bisa dilakukan di dalam rumah, dan chaos mulai muncul di rumah. Lain halnya dengan sungai, sungai telah dieksploitasi, diintervensi, dan diatur dengan berbagai alasan kemanusiaan. Kebuasan sungai semakin tidak tampak, dan sungai banyak yang mati karena airnya telah tercemar. Kondisi bulan Juni yang selalu hujan tidak lagi seperti pada masa lalu, yang airnya melimpah ruah dan mengalir deras. Ketika pada mulanya sungai merupakan space yang cair, yang seolah tidak memiliki kontrol, pada akhirnya sungai bisa dikendalikan oleh manusia. Sungai di-order-kan.

Kondisi tersebut menandakan bahwa sungai-sebagai space yang cair-tidak lagi bisa ditemukan ketika mereka dewasa karena sungai telah dikontrol dan dikendalikan oleh masyarakat di sekitar Ayemenem. Kecairan justru bergeser ke rumah karena rumah tidak lagi dikontrol. Aturannya berbeda dengan rumah yang dulunya masih menjaga batas-batas.

Jika pembahasan tentang post-space yang ada di luar rumah Ayemenem tertuju pada sungai, terlihat bahwa anak-anak juga memanfaatkan sungai sebagai space yang bebas, yang cair, di mana mereka bisa melarikan diri dari tekanan yang ada di Ayemenem, mengingat bahwa pada saat itu Ayemenem masih kuat dalam kontrol untuk menjaga order-nya. Suatu ketika, mereka juga bisa memanfaatkan ruang 
dalam rumah Ayemenem. Mereka tidak harus keluar karena kondisi Ayemenem yang sudah sangat kacau, peraturan tidak lagi ditegakkan.

Dalam pembahasan sebelumnya, seolah pelanggaran hanya bisa dilakukan di luar rumah. Namun demikian, ketika kondisi rumah sudah sangat chaotic, pelanggaran bisa terjadi di dalam rumah pula. Salah satu contohnya adalah peristiwa inses. Inses yang dimaksud di sini adalah hubungan seksual antara saudara kandung. Inses merupakan suatu tindakan yang tidak diperbolehkan dalam aturan manapun pada saat itu. Tradisi tidak menghendaki inses, mengingat mencintai seseorang saja ada aturan kasta yang berlaku pada masyarakat Kerala-rumah Ayemenem, terlebih inses yang sesama saudara, yang dilahirkan dari satu rahim. Demikian pula dengan aturan kolonial yang tidak mengijinkan adanya inses. Dengan demikian, dapat dikatakan bahwa inses berada di luar batas, baik itu batas tradisi maupun batas kolonial.

Peristiwa inses yang dilakukan oleh Rahel dan Estha merupakan, antara lain, ungkapan atas tekanan yang mereka dapatkan. Mereka dipisah oleh aturan yang ada dalam rumah Ayemenem yang menghendaki anak lakilaki tinggal bersama ayahnya ketika orangtua mereka berpisah. Seperti ungkapan Ammu ketika akan mengirim Estha ke ayahnya "Maybe they're right," Ammu's whisper said. "Maybe a boy does need a Baba." Rahel saw that her eyes were a redly dead (Roy: 32). Namun demikian, justru keterpisahan itu mendorong mereka untuk bersatu kembali. Keterpisahan itu yang memicu adanya post-space, tindakan di luar batas aturan tradisi maupun kolonial. Hal ini merupakan alternatif yang ditawarkan oleh penulis, bahwa inses adalah sebagai suatu space yang diakibatkan karena transgresi atas pembatasan (yang berupa aturanaturan) yang dialami oleh anggota keluarga, sebagai representasi masyarakat pascakolonial India.

Inses yang dilakukan oleh Rahel-Estha terjadi di kamar Ammu, kamar tempat ibunya dan mereka berdua yang harus patuh terhadap aturan tidur siang. Ia juga kamar tempat ibunya dikurung setelah hubungannya yang terlarang dengan Velutha telah diketahui. Kamar yang dulu masih harus dikunci pintunya, sekarang tidak. Ketika Rahel dan Estha kembali di masa dewasanya, ketika rumah sudah chaotic, maka kamar ini juga mengalami kekacauan atas ordenya.

\section{Kesimpulan dan Refleksi}

Berdasarkan uraian di atas, dapat disimpulkan bahwa novel ini membangun suatu keteraturan yang dioposisikan dengan kekacauan, yang seolah menjadi solusi atas fiksasi dari rumah. Namun, suatu saat bangunan tersebut ditolak sendiri, dengan menjadikan sesuatu yang dari awal dianggap sebagai postspace berubah menjadi space, misalnya dalam fenomena sungai yang setelah berpuluh-puluh tahun akhirnya bisa dikendalikan manusia. Artinya, ia menjadi suatu space yang ber-border. Di lain pihak, setelah berpuluh-puluh tahun, kondisi rumah menjadi sangat chaotic, di mana rumah yang semula dianggap sebagai sesuatu yang rigid bisa menjadi peluang terjadinya postspace. Dengan demikian, novel ini membongkar apa yang sudah dibangun sebelumnya dengan cara melawan order dengan chaos, kemudian chaos dan post-space juga dikonstruksi menjadi order. Inilah alternatif yang ditawarkan oleh novel ini, di mana solusi transgresi yang berupa post-space bukanlah akhir karena akan ada order baru, yang setelahnya dimungkinan juga muncul post-space baru.

Dengan demikian, dapat dikatakan bahwa novel ini secara terus-menerus menentang konstruksi yang dibentuk. Konstruksi berbatas tersebut bisa dilawan dengan menjadikannya post-space, dan post-space yang sudah ada juga dibatalkan dengan membentuk space yang berbatas. Setelahnya, nanti juga mungkin akan muncul space yang baru lagi. Alternatif yang ditawarkan oleh penulis melalui novel ini adalah dengan cara selalu melawan konstruksi yang diciptakan, bahkan konstruksi pascakolonial sendiri.

Refleksi yang dapat diambil adalah bahwa sejak awal novel ini tidak membuat oposisi antara konsep Barat dan Timur, 
namun menyandingkan keduanya, atau novel ini melampaui orientalisme dimana Barat dan Timur tersebut cenderung menekan. Hal ini juga dikarenakan novel tersebut berangkat dari kondisi pascakolonial dimana permasalahan berawal. Permasalahan tidak berawal dari kondisi kolonial, namun dari kondisi dualistik masyarakat pascakolonial. Jika dikaitkan dengan konteks masyarakat pascakolonial India, memang India adalah masyarakat yang dualistik, menjalankan konsep kolonial dan tidak meninggalkan tradisi Indianya. Dengan demikian, strategi yang ditawarkan pun tidak menganggap postspace sebagai penyelesaian akhir. Kemudian, jika dikaitkan dengan konsep Upstone bahwa permasalahan berangkat dari kolonial yang ingin dibongkar, maka dalam novel ini permasalahn justru berawal dari kondisi pascakolonial.

\section{Daftar Pustaka}

Gopal, Priyamvada. 2009. The Indian English Novel: Nation, History and Narration. New York; Oxford University Press.

Kulper, Kathleen. 2011. The Culture of India. New York: Britannica Educational Publishing.

Loomba, Ania. 2005. Colonialism/

Postcolonialism. New York: Routledge.

Mukerjee, Upamayu P. 2010. Postcolonial Environments. London: Palgrave Macmilan.

Roy, Arundhati. 2008. The God of Small Things. New York: Random House.

Singh, Jyotsna G. 2005. Colonial Narratives/ Cultural Dialogues: "Discoveries" of India in the Language of Colonialism. London: Roudledge.

Stein, Burton. 2010. A History of India. Oxford: Wiley-Blackwell.

Tickell, Alex. 2007. Arundhati Roy's The God of Small Things. London: Routledge.

Upstone, Sara. 2009. Spatial Politics in the Postcolonial Novel. Farnham Surrey: Ashgate Publishing Company. 